Original Research Paper

\title{
Phylogenetic Analysis of Rasbora spp. Based on the Mitochondrial DNA COI gene in Harapan Forest
}

\author{
Ahmad Subari ${ }^{1 *}$, Abdul Razak ${ }^{1}$, Ramadhan Sumarmin ${ }^{1}$ \\ ${ }^{1}$ Program Studi Pendidikan Biologi FMIPA, Universitas Negeri Padang, Padang, Indonesia.
}

\author{
Article History \\ Received : January $05^{\text {th }}, 2021$ \\ Revised : January $08^{\text {th }}, 2021$ \\ Accepted : January $18^{\text {th }}, 2021$ \\ Published : January $22^{\text {th }}, 2021$
}

*Corresponding Author: Ahmad Subari,

Program Studi Pendidikan Biologi FMIPA, Universitas Negeri Padang, Padang, Indonesia;

Email:

subary_ahmad@yahoo.com

\begin{abstract}
Harapan forest is the remaining lowland tropical forest in Sumatra which represents about 20 percent of the biodiversity on the island of Sumatra. There are several Rasbora species found in the Sungai Kapas Tengah River Refuge in the Harapan Jambi Forest that the relationship is not yet known. This research aims to know kinship and genetic distance several species of Rasbora from Sungai Kapas Tengah, Hutan Harapan Jambi. The method in this research using secondary data from the NCBI website ((National Center for Biotechnology Information). The data taken, namelynucleotide sequence from the Cytochrome Oxidase I (COI) gene in mitochondrial DNA. The Rasbora species analyzed were Rasbora from identification results in the Sungai Kapas Tengah River Refuge, Harapan Jambi Forest, consisting of, Rasbora bankanensis, $R$. caudimaculata, $R$. cf. sumatrana, $R$. dusonensis, R. elegans, $R$. sumatrana, and $R$. trilineata. Based on phylogenetic analysis, the location of the branch length in each Rasbora species, the closest kinship is owned byR. sumatrana and R. elegans species. Based on the results of genetic distance analysis, the closest genetic distance was the species $R$. elegans and $R$. sumatrana, with a distance value of $0.023(2.3 \%)$. While the farthest genetic distance between $R$. bankanensis and $R$. caudimaculata, with a distance value of $0.172(17.2 \%)$. Based on research results It can be concluded that $R$. bankanensis has a greater kinship and genetic distance value than other Rasbora species, so that this species forms a separate group. Meanwhile, 5 other species have kinship and the value of close genetic distance so that these species are united in the same group. For future researchers, it is hoped that some additional families of fish species will be analyzed for phylogenetic analysis in Sungai Kapas, Hutan Harapan Jambi, so that they can find out the relationship of several other species.
\end{abstract}

Keywords: COI Gene, Harapan Forest, Phylogenetic, Rasbora.

\section{Pendahuluan}

Hutan Harapan adalah hutan tropis dataran rendah yang tersisa di Sumatera yang merepresentasikan sekitar 20 persen keanekaragaman hayati di pulau Sumatera. Kawasan hutan ini merupakan konsesi Restorasi Ekosistem pertama di Indonesia. Berlokasi di perbatasan Provinsi Jambi dan Sumatera Selatan dengan luas 98.555 hektare (Hutan Harapan, n.d.). Menurut Sukmono et al. (2013, p. 162) terdapat beberapa sungai, danau serta rawa utama di Hutan Harapan yaitu, Sungai Kapas,
Sungai Lalan, Sungai Kandang, Danau 41, Danau Camp, Danau Rohani, Danau Tiung Luput, dan Rawa Klompang (mewakili $\pm 40 \%$ dari badan air yang ada di Hutan Harapan).

Berdasarkan Penelitian yang dilakukan oleh Sukmono et al. (2020) tentang Biodiversitas Ikan di Refuge Area Sungai Kapas Tengah Hutan Harapan Jambi didapatkan 375 ekor ikan, meliputi 50 spesies, 29 genus, dan 14 famili, serta 6 ordo. Enam Famili dengan jumlah spesies terbanyak meliputi, Cyprinidae (29 spesies), Siluridae (4 spesies), Bagridae (3 speseis) dan Nemachelidae dan Zenatchopteridae masing- 
masing 2 spesies. Genus dari Famili Cyprinidae yang paling banyak ditemukan adalah genus Rasbora.

Rasbora adalah jenis ikan air tawar berukuran kecil yang banyak terdapat di sungaisungai di daerah asia tenggara, termasuk Malasya, Brunei, dan Indonesia (Setiyo, n.d.). Berdasarkan hasil idetifikasi yang dilakukan oleh (Sukmono et al., (2020) dengan melihat karakter morfologi (morfometrik dan meristik) terdapat beberapa spesies Rasbora yang ditemukan di Refuge Area Sungai Kapas Tengah Hutan Harapan Jambi yaitu, Rasbora bankanensis, $R$. caudimaculata, $R$. cf. sumatrana, $R$. dusonensis, $R$. elegans, $R$. sumatrana, dan $R$. trilineata. Beberapa jenis Rasbora ini belum diketahui secara pasti hubungan kekerabatannya, karena identifikasi yang dilakukan hanya sebatas morfologi saja. Sehingga penting untuk dilakukan analisis filogenetik dari masingmasing spesies Rasbora yang telah terindentifikasi tersebut.

Analisis Filogenetik adalah analisis yang bertujuan untuk menyusun hubungan filogenetik yang pada umumnya digambarkan dalam suatu garis yang bercabang-cabang seperti pohon yang disebut pohon filogenetik (Irawan, 2013, p. 284). Pohon filogeni adalah suatu bentuk gambaran dari silsilah makhluk hidup baik hewan maupun tumbuhan yang bercabang-cabang menyerupai pohon (Lubis, 2014, p. 68). Analisis filogenetik dengan menggunakan data molekuler seperti DNA atau protein dapat menggambarkan hubungan evolusi antar spesies (Dharmayanti, 2011). Data yang digunakan yaitu sekuens Gen Sitokrom Oksidase I (COI) DNA Mitokondria.

Gen mikotokondria Sitokrom Oksidase I terbukti sangat berfungsi dalam identifikasi spesies untuk berbagai kelompok hewan (Hajibabaei et al., 2006, p. 959). Gen COI Mitokondria memiliki evolusi yang lebih cepat dibandingkan dengan DNA inti (Tamura et al., 2011). Ditambahkan oleh Herbert et al. (2003) metode untuk validasi spesies dengan menggunakan gen COI yang terletak pada mitokondria ini mampu menelusuri variasi basa nukleotida pada setiap spesies. Selain itu gen COI Mitokondria sudah banyak digunakan dalam identifikasi ikan pada umunya, diantaranya yaitu pada beberapa jenis ikan gabus (Channa spp.) (Irmawati et al., 2018), Ikan patin siam
(Pangasius hypopthalmus) dan ikan riu (Pangasius macronema) (Pratama et al., 2017), beberapa jenis ikan pari (Dasyatis spp.) dari famili Dasyatidae (Setiati et al., 2018), dan beberapa jenis ikan introduksi dari famili Poeciliidae (Rahayu et al., 2019). Gen COI yang dianalisis ini adalah gen dari hasil identifikasi dari beberapa spesies Rasbora di Refuge Area Sungai Kapas Tengah Hutan Harapan Jambi yang didapatkan dari website NCBI (National Centre for Biotechnology Information).

Berdasarkan uraian latar belakang masalah, maka perlu dilakukan penelitian Analisis filogenetik Ikan Seluang (Rasbora spp.) Berdasarkan Gen Sitokrom Oksidase I (COI) DNA Mitokondria di Sungai Kapas Tengah Hutan Harapan Jambi untuk mengetahui kekerabatan serta jarak genetik masing-masing spesies dalam genus Rasbora.

\section{Bahan dan Metode}

\section{Waktu dan Tempat}

Penelitian ini menggunakan data sekunder yang berasal dari website NCBI ((National Centre for Biotechnology Information). Data sekunder adalah data yang dibuat oleh orang yang tidak ikut serta dalam suatu peristiwa atau kondisi yang sedang diteliti (Hidayat et al., 2018, p. 10). Data yang diambil yaitu sekuens nukleotida dari gen Sitokrom Oksidase I (COI) pada DNA mitokondria. Spesies Rasbora yang akan dianalisis (spesies in group) yaitu Rasbora dari hasil identifikasi di Refuge Area Sungai Kapas Tengah Hutan Harapan Jambi yang terdiri atas, Rasbora bankanensis, $R$. caudimaculata, $R$. $c f$. sumatrana, $R$. dusonensis, $R$. elegans, $R$. sumatrana, dan $R$. trilineata. Dalam hal ini $R$. $c f$. sumatrana tidak dilakukan analisis filogenetik karena berdasarkan nama tersebut mengandung kata "cf" (confer). Singkatan "cf" dipakai identifikasi nama belum pasti (Heriyanto \& Ristiyanto, 2017). Sedangkan spesies out group (spesies pembanding) yang dipilih adalah ikan gabus (Channa striata)

\section{Analisis data}

Data sekuens nukleotida gen COI yang diperoleh dilakukan pengeditan dengan pensejajaran sekuens dengan Clustal-W menggunakan software MEGA X. Sekuens yang 
memiliki banyak kemiripan dipotong pada ujung 5', ujung 3' atau keduanya (Anafarida, 2020). Selanjutnya dilakukan analisis filogenetik dan jarak genetik menggunakan metode Neighbor joining dan model evolusi Kimura 2-parameter model dengan bootstrap sebanyak 1000.

\section{Hasil dan Pembahasan}

\section{Analisis Filogenetik}

Hasil analisis filogenetik pada ikan seluang (Rasbora spp.) terdiri atas 2 kelompok in group dan 1 kelompok out group. Kelompok in group terbagi menjadi klad besar dan kecil. Klad besar yaitu pada klad I sedangkan klad kecil yaitu pada klad II. Adapun filogenetik ikan seluang (Rasbora spp.) dapat dilihat pada gambar 1.

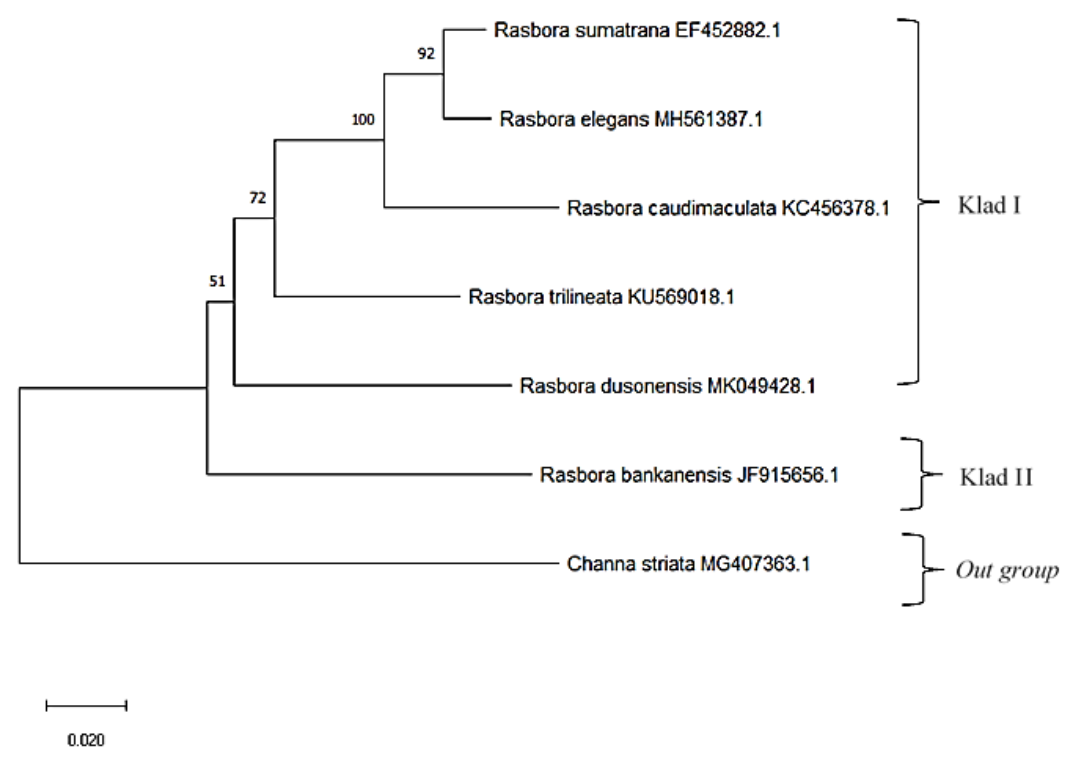

Gambar 1. Pohon filogenetik original Rasbora dengan 6 spesies in group dan 1 spesies out group berdasarkan Gen COI DNA dengan metode Neighbor Joining

Klad I Terdiri atas 5 spesies yaitu Rasbora sumatrana, $R$. elegans, $R$. caudimaculata, dan $R$. trilineata dan $R$. dusonensis. Jenis-jenis tersebut disatukan oleh banyaknya urutan sekuens yang memiliki kemiripan yang sama. Pada klad ini terdapat 2 spesies yang memiliki hubungan yang dekat yaitu R.sumatrana, dan R. elegans dengan nilai bootstrap 92. Dijelaskan oleh Dharmayanti (2011, p. 9) nilai bootstrap merupakan nilai yang digunakan untuk menguji seberapa baik set data model yang kita gunakan, jika nilai bootstrap rendah maka sekuen dari analisis untuk mendapatkan sebuah pohon filogenetika menjadi tidak dapat dipercaya. Ditambahkan oleh Muzzazinah (2017, p. 33) pohon filogenetik yang tinggi dan baik adalah pohon filogenetik dengan nilai bootstrap diatas 70 .

Pada Klad II terdiri atas satu spesies yaitu $R$. bankanensis. Spesies ini terpisah dari spesies Rasbora yang lainnya, namun spesies ini memiliki hubungan kekerabatan dengan $R$. dusonensis dengan nilai bootsrap 51. Pada out group, spesies yang digunakan adalah ikan gabus (Channa striata). Dijelaskan oleh Pangestika et al. (2015, p. 12) out group sangat dibutuhkan dalam pembuatan pohon filogenetik. Out group bertujuan untuk mengetahui karakter primitif (plesiomorf) dan karakter derivat (apomorf) dari kelompok in group serta untuk menentukan titik awal pembentukan sebuah pohon filogenetik (Muzzazinah, 2017, p. 27)

Berdasarkan analisis filogenetik, letak panjang cabang pada masing-masing spesies Rasbora, kekerabatan terdekat dimiliki oleh spesies $R$. sumatrana dan $R$. elegans karena memiliki panjang cabang yang terpendek dibandingkan dengan spesies Rasobora yang lainnya. Sedangkan kekerabatan yang jauh yaitu pada spesies $R$. bankanensis sehingga spesies ini terpisahkan dari spesies Rasbora yang lainnya 
dan membentuk kelompok tersendiri. Ditambahkan oleh Zein \& Sulandari (2009, p. 44) semakin panjang cabang pohon filogenetik maka semakin besar perubahan evolusi yang terjadi sehingga semakin jauh pula kekerabatannya. Analisis filogenetik diperkuat dengan nilai perhitungan jarak geneitk (pairwise distance). Adapun jarak genetik masing-masing ikan seluang (Rasbora spp.) dapat dilihat pada tabel 1.

Tabel 1. Jarak genetik ikan seluang (Rasbora spp.)

\begin{tabular}{lcccccc}
\hline \multicolumn{1}{c}{ Spesies } & 1 & 2 & 3 & 4 & 5 & 6 \\
\hline Rasbora trilineata & & & & & & \\
Rasbora sumatrana & 0.094 & & & & & \\
Rasbora elegans & 0.098 & 0.023 & & & & \\
Rasbora dusonensis & 0.128 & 0.138 & 0.136 & & & \\
Rasbora caudimaculata & 0.125 & 0.078 & 0.065 & 0.149 & & \\
Rasbora bankanensis & 0.137 & 0.147 & 0.161 & 0.164 & 0.172 & \\
Channa striata & 0.257 & 0.256 & 0.261 & 0.256 & 0.269 & 0.266 \\
\hline
\end{tabular}

Berdasarkan hasil analisis jarak genetik dapat diketahui bahwa jarak genetik terdekat adalah pada spesies $R$. elegans dengan $R$. sumatrana. Nilai jarak genetik kedua spesies tersebut yaitu $0,023(2,3 \%)$. Hal ini sesuai dengan kekerabatan yang dimilikinya. Kedua spesies ini memiliki persamaan kekerabatan yang hampir sama satu sama lainnya. Sedangkan jarak genetik terjauh pada masing-masing spesies Rasbora yaitu spesies $R$. bankanensis dengan $R$. caudimaculata. Nilai jarak genetik pada keduanya yaitu $0,172(17,2 \%)$. Ditambahkan oleh Dharmayanti (2011) semakin rendah nilai pairwise distance (jarak genetik) maka semakin dekat kekerabatannya.

\section{Kesimpulan}

Berdasarkan hasil penelitian dapat disimpulkan bahwa Rasbora bankanensis memiliki hubungan kekerabatan dan nilai jarak genetik yang jauh dibandingkan spesies Rasbora yang lainnya, sehingga spesies ini membentuk kelompok (Klad) tersendiri. Sedangkan 5 spesies lainnya yaitu Rasbora sumatrana, $R$. elegans, $R$. caudimaculata, $R$. trilineata dan $R$. dusonensis, memiliki hubungan kekerabatan dan nilai jarak genetik yang dekat sehingga spesies ini disatukan pada kelompok yang sama.

Bagi peneliti selanjutnya, diharapkan menambah beberapa famili dari jenis ikan yang akan dianalisis filogenetiknya di Sungai Kapas Hutan Harapan Jambi tersebut, sehingga dapat mengetahui hubungan kekerabatan beberapa jenis spesies lainnya.

\section{Ucapan terima kasih}

Ucapan terima kasih kepada Hanif Adienda, S.Pd yang telah memberikan saran, motivasi, serta masukan dalam penulisan artikel.

\section{Referensi}

Anafarida, O., \& Badruzsaufari, B. (2020). Analisis Filogenetik Mangga (Mangifera Spp.) Berdasarkan Gen 5, 8s Rrna. Ziraa'ah Majalah Ilmiah Pertanian, 45(2), 120-126. https://ojs.uniskabjm.ac.id/index.php/ziraah/article/view/3 001

Dharmayanti, N. I. (2011). Filogenetika Molekular: Metode Taksonomi Organisme Berdasarkan sejarah Evolusi. Filogenetika Molekular: Metode Taksonomi Organisme Berdasarkan Sejarah Evolusi, 30, 1-10. https://doi.org/http://dx.doi.org/10.14334/ wartazoa.v21i1.948

Hajibabaei, M., Smith, M. A., Janzen, D. H., Rodriguez, J. J., Whitfield, J. B., \& Hebert, P. D. N. (2006). A minimalist Barcode Can Identify a Specimen Whose DNA is Degraded. Molecular Ecology Notes, 6(4), 959-964.

https://doi.org/https://doi.org/10.1111/j.14 71-8286.2006.01470.x 
Hebert, P. D. N., Ratnasingham, S., \& DeWaard, J. R. (2003). Barcoding animal life: Cytochrome c oxidase subunit 1 divergences among closely related species. Proceedings of the Royal Society B: Biological Sciences, 270(SUPPL. 1). https://doi.org/10.1098/rsbl.2003.0025

Heriyanto, B., \& Ristiyanto. (2017). Binatang Penular Penyakit di Sekitar Lingkungan Rumah. Yayasan Pustaka Obor Indonesia. https://books.google.co.id/books?id=M3

Hidayat, I. W., Ariana, A. D., Hendriani, W., Zein, R. A., Cahyono, R., \& Wicaksono, D. A. (2018). Keterampilan Belajar (Study Skills) Untuk Mahasiswa (Pertama). Kencana.

https://books.google.co.id/books?id=mK5

Hutan Harapan. (n.d.). Retrieved December 31, 2020, from https://hutanharapan.id/

Irawan, B. (2013). Karsinologi Dengan Penjelasan Deskriptif dan Fungsional. Airlangga University Press. https://books.google.co.id/books?id=Lh3I

Irmawati, I., Tresnati, J., Fachruddin, L., Arma, N. R., \& Haerul, A. (2018). Identifikasi ikan gabus, Channa spp. (Scopoli 1777) stok liar dan generasi I hasil domestikasi berdasarkan gen Cytochrome C Oxidase Subunit I (COI). Jurnal Iktiologi Indonesia, $\quad 17(2), \quad 165$. https://doi.org/https://doi.org/10.32491/jii .v17i2.356

Lubis, K. (2014). Cara Pembuatan Pohon Filogeni. Jurnal Pengabdian Kepada Masyarakat, 20(75), 66-69. https://doi.org/https://doi.org/10.24114/jp km.v20i75.4812

Muzzazinah. (2017). Metode filogenetik pada indigofera. Prosiding Seminar Nasional Pendidikan Biologi Dan Biologi, Rifai 2011,

25-40. http://seminar.uny.ac.id/sembioun y2017/prosiding/metode-filogenetik-pada -indigofera

Pangestika, Y., Budiharjo, A., Pancasakti, H., \& Kusumaningrum. (2015). Analisis Filogenetik Curcuma Zedoaria (Temu Putih) Berdasarkan Gen Internal Transcribed Spacer (ITS). Jurnal Akademika Biologi, 4(4), 8-13. https://ejournal3.undip.ac.id/index.php/bi ologi/article/view/19424

Pratama, M. R. N., Syaifudin, M., \& Muslim, M. (2017). Aplikasi DNA Barcode Pada Ikan Patin Siam (Pangasius hypopthalmus) dan Ikan Riu (Pangasius macronema) Berdasarkan Gen Sitokrom C Oksidase Subunit I ( COI ) DNA Barcode. Prosiding Seminar Nasional Lahan Suboptimal, 472-481. https://repository.unsri.ac.id/22077/1/44_ SDH REVISI M_ RIFQI NANDA.pdf

Rahayu, D. A., Nugroho, E. D., \& Listyorini, D. (2019). DNA Barcoding Ikan Introduksi Khas Telaga Sari, Kabupaten Pasuruan. Biotropika: Journal of Tropical Biology, $7(2)$,

51-62. https://biotropika.ub.ac.id/index.php/biotr opika/article/view/530/336

Setiati, N., Peniati, E., \& Maharani, R. I. (2018). Status Konservasi Jenis Ikan Pari Yang Diperdagangkan di TPI Di Kota Semarang Berdasarkan Gen Coi Mitokondria. Seminar Nasional Biologi Dan Pendidikan Biologi UKSW, 233-239. https://repository.uksw.edu/handle/12345 6789/15329

Setiyo, M. (n.d.). Biota Dunia Perairan. 22/7/2017. Retrieved December 31, 2020, from

https://www.dunia-perairan.com/2017/07/ ikan-seluang-rasbora-sp.html

Sukmono, T., Solihin, D. D., Rahardjo, M. F., \& Affandi, R. (2013). Iktiofauna di perairan hutan tropis dataran rendah, Hutan Harapan Jambi. Jurnal Iktiologi 
Subari, A. et al. (2021). Jurnal Biologi Tropis, 21 (1): 89 - 94

DOI: http://dx.doi.org/10.29303/jbt.v21i1.2351

Indonesia, $\quad 13(2), \quad 161-$

174. https://doi.org/https://doi.org/10.324

91/jii.v13i2.103

Sukmono, T., Wulandari, T., \& Kurniawan, W. (2020). Biodiversitas Ikan Di Refuge Area Sungai Kapas Tengah Hutan Harapan Jambi Sebagai Database Aplikasi Go Iwak. Biospecies, 13(1), 29-36. https://doi.org/https://doi.org/10.22437/bi ospecies.v13i1.7945

Tamura, K., Peterson, D., Peterson, N., Stecher, G., Nei, M., \& Kumar, S. (2011). MEGA5: Molecular evolutionary genetics analysis using maximum likelihood, evolutionary distance, and maximum parsimony methods. Molecular Biology and Evolution, 28(10), 2731-2739. https://doi.org/10.1093/molbev/msr121

Zein, M. S. A., \& Sulandari, S. (2009). Investigasi Asal Usul Ayam Indonesia Menggunakan Sekuens Hypervariable-1 D-loop DNA Mitokondria. Jurnal Veteriner, $\quad 10(1), \quad 41-49$. https://ojs.unud.ac.id/index.php/jvet/articl e/view/3345 